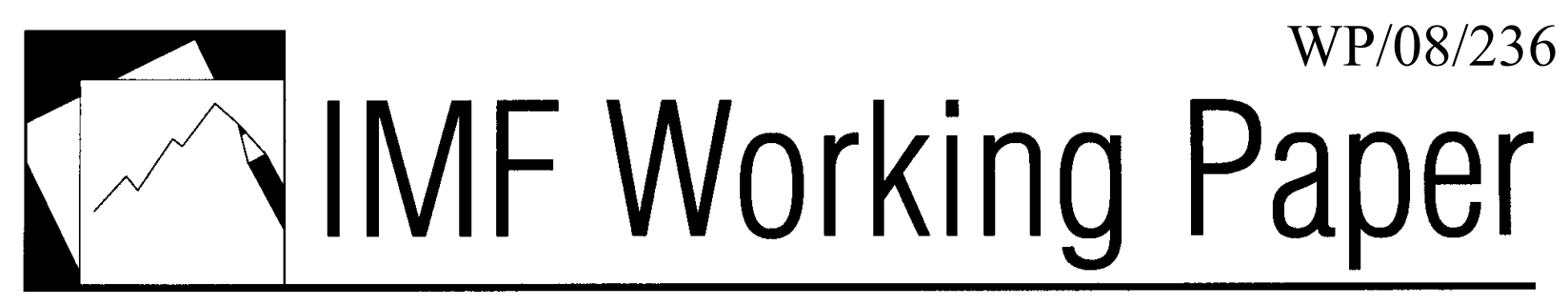

\title{
A Theory of International Crisis Lending and IMF Conditionality
}

Olivier Jeanne, Jonathan D. Ostry, and

Jeromin Zettelmeyer 



\title{
IMF Working Paper
}

Research Department

\section{A Theory of International Crisis Lending and IMF Conditionality \\ Prepared by Olivier Jeanne, Jonathan D. Ostry, and Jeromin Zettelmeyer ${ }^{1}$}

October 2008

\begin{abstract}
This Working Paper should not be reported as representing the views of the IMF. The views expressed in this Working Paper are those of the author(s) and do not necessarily represent those of the IMF or IMF policy. Working Papers describe research in progress by the author(s) and are published to elicit comments and to further debate.

We present a framework that clarifies the financial role of the IMF, the rationale for conditionality, and the conditions under which IMF-induced moral hazard can arise. In the model, traditional conditionality commits country authorities to undertake crisis resolution efforts, facilitating the return of private capital, and ensuring repayment to the IMF. Nonetheless, moral hazard can arise if there are crisis externalities across countries (contagion) or if country authorities discount crisis costs too much relative to the national social optimum, or both. Moral hazard can be avoided by making IMF lending conditional on crisis prevention efforts- "ex ante" conditionality.
\end{abstract}

JEL Classification Numbers:F02, F33, F34

Keywords: International Monetary Fund; crisis prevention; ex ante conditionality Author’s E-Mail Address: ojeanne@imf.org; jostry@imf.org; jzettelmeyer@imf.org

\footnotetext{
${ }^{1}$ We are grateful to Jim Boughton, Rex Ghosh, Alberto Martin, Jaume Ventura, Xavier Vives, and seminar participants at the IMF, UPF, and IESE for comments and suggestions.
} 


\section{Contents}

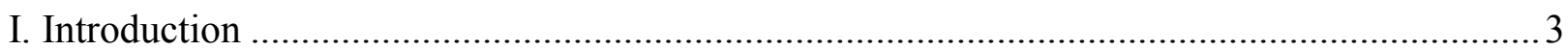

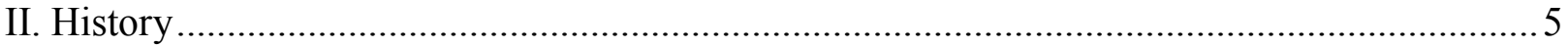

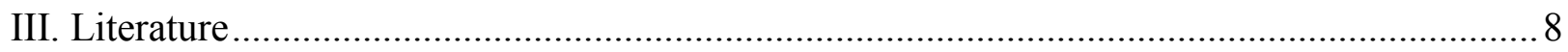

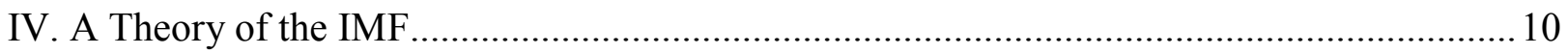

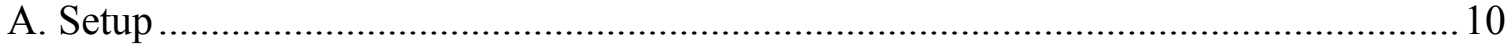

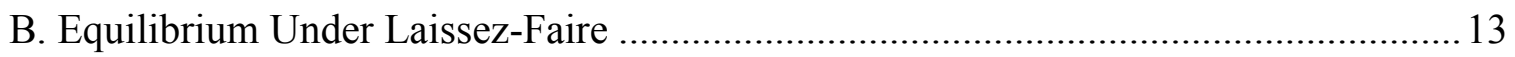

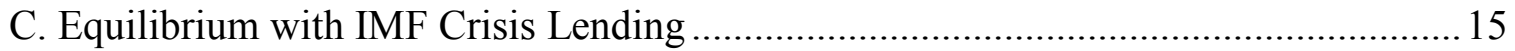

D. Moral Hazard in the Presence of IMF Crisis Lending ................................................ 18

E. The Case for ex ante Conditionality ......................................................................2

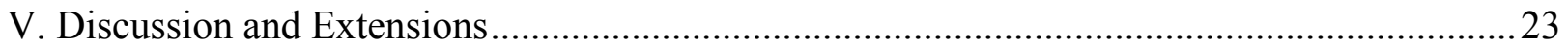

A. Incomplete Information and Imperfect Commitment by the IMF .............................22

B. Large versus Small Countries ………….............................................................2 24

C. Distortions Related to Domestic Political Economy .....................................................2 24

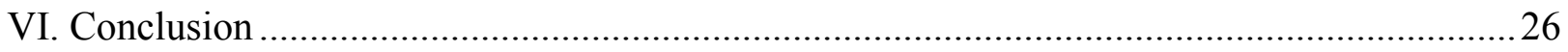

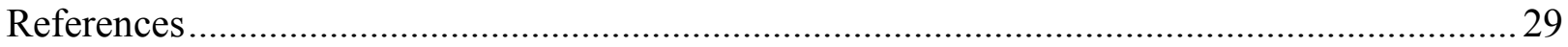




\section{INTRODUCTION}

Over the last ten years, the IMF's crisis lending policies have been at the center of debates on IMF reform. Some have questioned the objectives of IMF crisis lending, while others have been concerned with the "moral hazard" that such lending may generate, as well as the nature and extent of IMF conditionality. Protagonists in such debates often fail to reach consensus at least in part because they have different implicit models in mind, or use the same term, such as moral hazard, to mean different things. It does not help, from that point of view, that there is no theoretical framework able to encompass the wide range of arguments that are made about IMF crisis lending and conditionality.

The purpose of this paper is to propose such a framework, and then to study the implied mapping from assumptions to policy implications. The questions that this framework will help to address include: Should the IMF act as a lender of last resort that lends exclusively to "illiquid but solvent" countries? Does official crisis lending generate moral hazard and, if so, through which channels? What should be the main purpose of conditionality? Should it be to minimize the welfare cost of crises, to ensure that the IMF's loans get repaid, or to ensure that foreign investors are repaid? Should conditionality be applied only ex post, accompanying IMF assistance in the event of crisis, or also ex ante, as a way of pre-qualifying countries that would be eligible for crisis loans?

The theoretical framework in this paper is based on the assumption that the IMF has a role to play in crises, because it is more effective than uncoordinated private investors in eliciting policy adjustments from crisis countries. As shown in more detail in the next section of this paper, the IMF achieved this ability over time by developing a "lending technology" based on tranched lending, close monitoring, and conditionality. Although this view of the IMF is not new - it is consistent with Tirole's (2002) view of the IMF as "delegated monitor" 2 and with Khan and Sharma's (2001) analysis of IMF conditionality as a form of collateral - this paper represents, to our knowledge, the first attempt to model this view of the IMF's role and draw its implications based on a rigorous welfare analysis. ${ }^{3}$

The main conclusions are as follows. First, if the IMF's purpose is to undertake crisis lending and not international transfers, it follows that it should lend only to solvent countries. However,

\footnotetext{
${ }^{2}$ The IMF acts as a delegated monitor for the creditors ex post (in a crisis), which benefits the debtor country ex ante (when the borrowing takes place): "the IMF's role is to substitute for the missing contracts between the sovereign and individual foreign investors and thereby to help the host country benefit fully from is capital account liberalization. Accordingly, the IMF should act as a delegated monitor and a trustee for foreign interests precisely to facilitate the country's favorable access to foreign borrowing." (Tirole, 2003)

${ }^{3}$ See Federico (2001) for an earlier paper that models both ex post and ex ante conditionality within one framework. Ex ante conditionality has also been modeled by Jeanne and Zettelmeyer (2001a) and Weithöner (2006), and is implicit in the analysis of Gale and Vives (2002). See also the survey by Frech (2005).
} 
the prescription of lending only to "illiquid but solvent" countries is simplistic, not so much because this difference may not be perfectly observable (as is often argued), but because the perception of solvency is determined by expectations about future policies, which themselves are endogenous to the intervention of the IMF. The relevant question for a given crisis country is whether it is conditionally solvent, in the sense that the IMF can help to re-establish solvency through instruments in its toolbox - in particular, conditional tranched lending.

As regards moral hazard and conditionality, two questions are crucial:

- $\quad$ Is IMF ex post conditionality effective in re-establishing solvency?

- $\quad$ Are the objectives of domestic policymakers consistent with the maximization of global welfare? This will not be the case, for example, if policies or policy-related economic outcomes in one country impose a negative externality on other countries; or if the objectives of domestic policymakers do not fully coincide with domestic welfare maximization for political economy reasons.

We find that if the answer to both questions is positive, countries are likely to "produce" the optimal degree of crisis prevention effort, IMF lending does not generate moral hazard, and there is no reason to extend conditionality beyond measures that are required to reestablish solvency after a crisis. If, on the other hand, the answer to one (or both) of the above questions is negative, then countries are likely to produce a sub-optimal level of crisis prevention effort, IMF lending will create some moral hazard, and there may be a good case for mitigating this moral hazard through ex ante conditionality (or pre-qualification).

Our own reading of the evidence is that IMF lending to emerging market countries - which has always been repaid in full-does not involve substantial transfers, ${ }^{4}$ but that the answer to the second question may well be negative in some cases. In our baseline model, we analyze one reason why this may be the case, which is closely linked to the historical motives behind the creation of the IMF: cross-country externalities arising from the international spillovers of countries. In an extension, we analyze a second possible reason, namely, a standard political economy distortion, which implies that policymakers discount the future at an excessively high rate. We show that either of these distortions can lead countries to invest insufficiently in crisis prevention, and analyze the implications for the optimal design of conditionality associated with crisis lending.

\footnotetext{
${ }^{4}$ See Jeanne and Zettelmeyer (2001b) and Zettelmeyer and Joshi (2005) for details. Note that IMF lending to poor countries has been different in this regard, involving both heavily subsidized interest rates, and eventual deft relief. This has not been the case for middle income countries.
} 
In the sections that follow, we first sketch the historical context of the debate to which this paper speaks. We then briefly describe the academic literature on the themes of this paper-the rationale for IMF lending, the role of IMF conditionality, and the potential for IMF-induced moral hazard - focusing on theoretical work in this area. We next present our baseline model, which rationalizes the lending role of the IMF as it exists as present, shows how this role can potentially be welfare reducing in the presence of crisis spillovers across countries, and develops a solution to this problem (namely, to apply conditionality ex ante). In an extension, we show that similar welfare problems can arise in the presence of domestic political economy distortions rather than cross-country externalities, and that it leads to the same solution.

\section{History}

IMF conditionality developed gradually. From 1947 until the mid-1950s, the Fund allowed members to borrow without explicit conditions. A country requesting an IMF loan would make the case that it needed IMF resources consistent with the purposes of the Fund - namely, to give the country the "opportunity to correct a maladjustment in the balance of payments without resorting to measures destructive of national or international prosperity" - and the Fund would let it draw based on the merits of that case. ${ }^{5}$

The idea to commit members to policy actions coincided with the creation, in 1952, of a new instrument, the "Stand-By Arrangement," which provided countries with a time window over which they could draw from the Fund without having to make a new request. Initially, Stand-By Arrangements were granted for only six months, "as some Executive Directors had expressed the view that it would not be possible to foresee conditions in a member country for more than six months, and it was therefore inadvisable for the Fund to commit itself for a longer period" (Spitzer, 1969, p. 470). However, in 1954, Peru asked for a one year stand by arrangement. This was granted with the provision that Peru's right to draw could be interrupted if the IMF felt that "developments had occurred that would no longer justify the belief that [Peru's] Exchange Stabilization Program could be made effective." 6

"Prior notice" clauses of this type, which gave the Fund the option to effectively rescind StandBy Arrangements if it disagreed with member policies during the period of the arrangement, were incorporated in more than 30 Stand-Bys in the 1954-1960 period; in one case-Bolivia in 1958 - the clause was in fact used. However, these clauses remained controversial because they gave the Fund discretion on the issue of whether a country had deviated sufficiently from its original policy intention to justify "prior notice". Beginning in the late 1950s, the prior notice clause was replaced by explicit (and typically quantitative) fiscal and monetary "performance

\footnotetext{
5 Article I (v) of the IMF's Articles of Agreement. The evolution of IMF lending practices in the 1950s and early 1960s is described, in order of increasing detail, in Fleming (1964), Spitzer (1969), and Horsefield (1969). Boughton (2001, Chapter 13) provides a brief summary.

${ }^{6} 1954$ Stand-By Arrangement with Peru, paragraph 7, quoted in Spitzer (1969), p. 478.
} 
criteria" which set a verifiable standard for when an arrangement could be discontinued. In other words, the policy effort that the IMF expected countries to exert in order to be able to draw from the Fund was explicitly written into the arrangement. Several other elements that came to characterize Stand-By Arrangements were added by the early 1960s, including: periodic reviews of the agreed performance criteria by the IMF staff; "phased" drawings following these reviews; and guidelines for "waiving" performance criteria in the event of unforeseen shocks, and for negotiating new arrangements.

The result was a unique institutional apparatus - no analogous private sector framework for setting and monitoring lending conditions has ever developed-for minimizing the debtor moral hazard problem inherent in the relationship between the IMF and its borrowers. ${ }^{7}$ While countries could of course promise policy effort, draw once, and go "off track," they could not draw again without either meeting the agreed performance criteria or renegotiating, which required convincing the Fund that the new program was more credible than the previous one. Although the ultimate effect of IMF programs on economic outcomes has been controversial, ${ }^{8}$ the fact that agreed performance criteria have generally had a commitment effect on country policies is not. Furthermore, the fact that the IMF has generally been repaid in full constitutes prima facie evidence that IMF conditionality was effective by the standards of its original purpose, namely, to safeguard Fund resources. ${ }^{9}$

In contrast, IMF conditionality was not designed to minimize moral hazard with respect to third parties, such as other countries, private creditors, or, in borrowing countries with less-thanbenevolent governments, the citizens of those countries. In principle, such moral hazard problems could occur when crises induced by poor policies have external effects through trade or financial linkages, or redistributive effects. In the context of the IMF of the 1950s and 1960s, however, these effects were arguably a lesser concern, for two reasons. First, the behavior of countries was constrained by other commitments associated with IMF membership — not to interfere with current payments, and not to adjust exchange rate parities except with the permission of the Fund - which were also viewed as the main channels for externalities on other members. Second, Fund supported arrangements were meant to address flow imbalances prior to a currency crisis or devaluation. In this sense, all IMF lending was intended to be pre-crisis lending (although this was not always the case in practice). Successful adjustment in the context of a Fund supported program meant preventing a crisis, and, therefore, its unpleasant effects on third parties.

\footnotetext{
${ }^{7}$ There are, however, predecessors to IMF conditionality in the context of official lending, particularly lending by the League of Nations: see Santaella (1993), and Khan and Sharma (2001) for an overview.

${ }^{8}$ See the survey by Haque and Khan (1998).

${ }^{9}$ The main exception is subsidized lending to low income countries, which was ultimately forgiven in many cases following the "highly indebted poor countries" (HIPC) and "multilateral debt relief" (MDRI) initiatives of the last decade (IMF, 2007b).
} 
This changed with the demise of the Bretton Woods system of fixed parities and the sharp rise of capital flows to developing countries. For the most part, the IMF code of conduct that constrained member policies in the original Articles of Agreement broke down, or became much more difficult to enforce. Moreover, IMF lending from this point on often occurred in the aftermath of currency, debt, or banking crises, and hence arguably affected incentives vis-à-vis parties that were not part of its "contract" with the country. By the early 1980s, critics of the Fund were charging that, by making it less painful for countries to reschedule their debts to the private sector, the Fund "encourages both further threats of default and further bank lending to borrowers which have proved themselves to be not creditworthy" (Vaubel, 1983). Some of the same critics also proposed a solution, namely, to apply conditionality ex ante rather than ex post, excluding countries with poor macroeconomic policies from access to IMF lending in the event of a crisis (Vaubel 1988). This idea remained unexploited, however, and IMF conditionality continued to focus on policy actions ex post, reflecting the prevailing view that IMF lending with ex post conditionality was unlikely to distort country incentives. ${ }^{10}$

Following the large crises of the 1990s, concerns that IMF "bailouts" could be a cause of moral hazard became more acute, both inside and outside the IMF. Critics such as Harvard University's Robert Barro argued that "the IMF doesn't put out fires, it starts them," and that it had better change its name to "IMH - the Institute for Moral Hazard." 11 At the same time, the question whether the IMF should require countries to meet ex ante conditions for drawing on its resources (at least for large scale drawings) became the subject of a wider debate. ${ }^{12}$ After much discussion, in 1999 the IMF created a new facility, the "Contingent Credit Line" (CCL) reserved for members with strong policies, without however spelling out specific ex ante conditions, and without changing the access rules for existing IMF facilities. In the event, the CCL did not attract any borrowers, in part, because it did not envisage a significantly lower

\footnotetext{
${ }^{10}$ Polak (1991), p. 54, writes: "Ex ante conditionality would be unlikely to work. It seems too much to hope that a government interested primarily in its own survival would be held back from unwise policies by the mere knowledge that the IMF would not stand ready to mitigate the severity of the eventual adjustment crisis." Implicit in this sentence is the view that traditional IMF lending was not a cause of unwise policies to begin with. In the context of the 1980s reschedulings, this is indeed a plausible view, since the interest subsidy implicit in IMF lending was "modest" (Polak, p. 55), and it was hard to argue that the IMF was facilitating redistribution from bank creditors to countries.

${ }^{11}$ Barro (1998). See also Wall Street Journal (April 23, 1998); Calomiris (1998a); Meltzer (1998); Willett (1999); Council on Foreign Relations (1999); Nunnenkamp (1999); Mussa (1999, 2004); International Financial Institutions Advisory Commission (2000); and Eichengreen (2000). An extensive empirical literature on moral hazard ensued. Key contributions include: Zhang (1999); Lane and Phillips (2000); Kamin (2002); Brealey and Kaplanis (2004); Haldane and Scheibe (2005); Dell'Ariccia, Schnabel, and Zettelmeyer (2006); and Lee and Shin (2007). Kim (2007) presents a calibrated model to gauge the potential moral hazard effect due the expected subsidy embodied in IMF loans (resulting from the riskiness of IMF lending).

${ }^{12}$ Calomiris (1998b), Council on Foreign Relations (1999), International Financial Institutions Advisory Commission (2000), Jeanne and Zettelmeyer (2001a,b; 2005), Kenen (2001), Cohen and Portes (2004), Cordella and Levy Yeyati (2005) and Ostry and Zettelmeyer (2005).
} 
burden in traditional (ex post) conditionality than standard IMF facilities, and it was allowed to lapse in $2003 .^{13}$

Two recent papers, written after the demise of the CCL, spelled out how ex ante conditionality might be integrated into IMF operations. Cordella and Levy Yeyati (2005) discuss ex ante conditionality in the context of a specific CCL-like lending facility. Ostry and Zettelmeyer (2005) make a case for the use of ex ante conditionality in all Fund lending. The idea in their paper is to use the IMF's surveillance process to rate all member countries based on the quality of their domestic policies and institutions such as financial sector regulation and supervision, debt levels and debt structure, fiscal and exchange rate policy, and data dissemination. Access to IMF resources would be based on the score received. For example, access to large scale crisis lending would be reserved for a group of high scorers; and some low scorers might be cut off from most IMF credit, while countries in between would enjoy "standard" access. They argue that this would improve incentives not just by encouraging good policies but also by limiting the flow of private capital to countries where it is unlikely to be used in socially beneficial ways.

\section{LITERATURE}

There appear to be four main strands of theoretical model that try to make sense of the IMF's role. ${ }^{14}$ First, a small set of papers, including Chami, Sharma, and Shim (2004) and Weithöner (2006), model the IMF as a risk sharing arrangement among countries. Private capital markets play no role in these models; instead, the IMF is interpreted as a contract and/or a fund providing loans or transfers to members hit by adverse shocks (possibly, as in Chami, Sharma and Shim, 2004, involving a specialized monitoring structure). Moral hazard in these models can arise through two channels: first, as in any model involving transfers or loans, through a potential or actual subsidy to the borrower or recipient. Second, and more interestingly, by aggravating an existing externality across countries. In Weithöner (2006), there are crisis spillovers across countries. This gives rise to moral hazard, as the level of crisis prevention effort that each country exercises is too low from a social point of view. The presence of an IMF safety net can aggravate this problem, by making crises less painful individually (of course, it could also mitigate the problem if it mitigates contagion, see Clark and Huang, 2001). The

\footnotetext{
${ }^{13}$ Recently, there has been an attempt to revive the idea of a large-scale credit window for qualified countries (the "Reserve Augmentation Line", or RAL, which is currently under discussion by the IMF's Executive Board; see IMF, 2006, 2007a). Compared to the CCL, the RAL would have a more clearly defined qualification framework while requiring less conditionality ex post.

${ }^{14}$ What follows does not pretend to be a complete survey of models involving the IMF. It leaves out, in particular, a literature on IMF conditionality focused on conflicts of interest between the IMF and the borrowing country and on program compliance (see Mosley, 1987, 1992; White and Morrissey, 1997; Bird, 1998; Killick, 1996, 1997, 1998; Hermes and Schilder, 1997, Drazen and Fischer, 1997, and Joyce, 2003). Similarly, it ignores papers on whether conditionality should be outcome-based rather than policy-based (Ivanova, 2006); and how streamlined conditionality should be (Erbas, 2003). The focus here is on models that rationalize the IMF's role in terms of correcting particular market or policy failures.
} 
potential solution to this problem is ex ante conditionality, i.e., conditioning the amount of IMF lending on the crisis prevention effort that countries exercise.

Second, there is a group of papers - motivated mainly by the IMF's role in the large crises of the 1990s - in which the IMF solves a pure coordination problem in international lending. Some are based on the traditional approach of modeling of coordination failures in terms of multiple equilibria (Sachs, 1984, 1995; Zettelmeyer, 2000; Jeanne and Wyplosz, 2001; Jeanne and Zettelmeyer, 2002). In more recent models, this modeling strategy is replaced by the "global games" approach, in which there is a unique equilibrium which may or may not involve a run on reserves, and in which the probability of a run depends on the available liquidity (Rochet and Vives, 2004, Morris and Shin, 2006; Corsetti, Guimarães and Roubini, 2006; Kim, 2006, 2007). It is possible to introduce an effort variable in those models and study the impact of IMF lending on policy incentives. For example, Corsetti, Guimarães and Roubini, 2006 show that the effect of IMF lending on policy effort is ambiguous: on the one hand, there is the standard debtor moral hazard effect driven by a potential transfer from the creditor to the debtor, but on the other, countries may actually want to exercise higher effort if the presence of IMF lending means that their efforts are more likely to succeed in averting a crisis (see also Penalver, 2004). But these models ignore IMF conditionality, and the coordination problem that the IMF solves could arguably be solved by any (large) lender, and even by mechanisms that involve no lending at all. ${ }^{15}$ Hence, while these models give a nice interpretation to why IMF lending can help in a crisis, they do not provide a very tight justification for the existence of the IMF.

Third, there is a new and growing literature that focuses on the role of the IMF in correcting information and incentive problems in international capital markets (Marchesi and Thomas, 1999; Federico, 2001; Clark and Huang, 2001; Tirole, 2002, Penalver, 2004; Jeanne and Zettelmeyer, 2005; de Resende, 2007). Some of these papers are motivated by crisis lending; others focus on the interactions of country policies, private financing, and the IMF in normal, that is non-crisis, times. The IMF's ability to impose conditionality and/or monitor the country is critical in these papers. In Marchesi and Thomas (1999), IMF-supported programs serve as screening devices; governments that pursue strong reforms ask for Fund conditionality as a way of credibly signaling their credentials. In several other papers, IMF conditionality acts as a commitment device: by committing the country to a higher policy effort, or more generally to actions that preserve creditor interests, the IMF catalyzes foreign capital flows and ultimately raises domestic consumption. In effect, the IMF acts as a substitute for a more complete contract between investors and the borrowing country. Tirole (2003) also discusses the complementarity between ex post conditionality and ex ante pre-qualification. He notes the parallel between IMF crisis lending and banking regulation and safety nets, as analyzed by Dewatripont and Tirole

\footnotetext{
${ }^{15}$ See, in particular, Miller and Zhang (2000) and Haldane and Kruger (2001), who propose payments standstills to resolve creditor coordination failures.
} 
(1994) in their integrated treatment of prudential regulation. In the case of banking regulation pre-qualification takes the form of proper risk management and capital adequacy requirements.

Finally, there is a literature, with contributions from both economists and political scientists, on the potential role of the IMF in mitigating domestic policy failures (Vreeland, 1999, Drazen, 2002, and Mayer and Mourmouras, 2002, 2004, 2005, Jeanne and Zettelmeyer, 2001a; Jeanne, Ostry and Zettelmeyer, 2007). The premise of these papers is that economic policies are determined not by a welfare maximizing government but by a domestic political economy equilibrium, and that the presence of the IMF - both through the assistance it offers, and through IMF conditionality - may change the equilibrium. Specifically, the presence of the Fund might strengthen the hand of a reformers in the face of domestic political opposition. This could happen because it changes the welfare of a reformist government, by tying the government's hands and hence strengthening its bargaining power, or because it affects the welfare of opposition groups directly.

The model presented in this paper straddles all four strands of this literature. As in Tirole (2003) and some of the related literature, conditionality endows the IMF with a better technology, relative to the private sector, for extracting policy effort from countries in crisis. This enables is to lend in situations when the private sector cannot, which mitigates the cost of crises. ${ }^{16}$ As a result, countries may have an incentive to reduce crisis prevention effort (as in Corsetti, Guimarães and Roubini (2006), the direction of this effect is ambiguous in general, because higher crisis prevention effort also has the effect of reducing crisis migation effort). In itself, this is not necessarily welfare reducing, because it could just be an efficient response to the presence of the IMF safety net. However, in the presence of additional distortions - either externalities across countries, as emphasized out by Weithöner (2006), or a domestic political economy failures, as emphasized by Jeanne and Zettelmeyer (2001a,b) —IMF crisis lending can indeed be welfare reducing if it leads to a reduction in crisis prevention effort. As we show, this may call for conditionality ex ante rather than just ex post.

\section{A THEORY OF THE IMF}

\section{A. Setup}

We consider a large number of small open emerging market economies, indexed by $i \in[0,1]$. There are three periods: $t=0,1,2$.

\footnotetext{
${ }^{16}$ Hence, unlike in the literature decribed as the "second strand" in the discussion above, the rationale for IMF lending is not primarily that it is a large lender relative to the private sector. This said, our model could also be extended, with relatively little change, to encompass this aspect, by introducing the possibility of self-fulfilling runs. This this would not change the main conclusions.
} 
In each country, the domestic private sector finances an investment by borrowing abroad in period 0 . Simultaneously the domestic government implements a "crisis-prevention effort" which determines the country' vulnerability to a crisis in period 1 . The investment pays off in period 2. Period 1 sees the arrival of some news on the future productivity of the investment. Depending on the news it is possible or not for the domestic private sector to roll over its external debt. We will make assumptions such that if the news is bad, the external debt is not rolled over and the investment is liquidated. (A possibility for the government to improve the situation by exercizing a "crisis-resolution" effort in period 1 will be introduced later.)

There is one homogeneous good, which is invested and consumed. The domestic private sector is modeled as a representative entrepreneur who invests $k_{i}$ in period 0 in the hope of receiving an output $y_{i}=\theta_{i} k_{i}$ in period 2. The representative domestic entrepreneur has no wealth to finance the investment, and must borrow $k_{i}$ from foreign lenders at interest rate $r_{i}$. Foreign lenders grant one-period loans only, so $k_{i}\left(1+r_{i}\right)$ must be rolled over in period 1 with a new loan. If foreign lenders do not roll over, the investment is liquidated and $y_{i}=0$. We denote by $r_{i}^{\prime}$ the interest rate at which debt is rolled over between period 1 and period 2. Both $r_{i}$ and $r_{i}^{\prime}$ will be endogenous to the equilibrium of the debt market. The international debt market is perfectly competitive and foreign investors request a zero expected return on their lending.

In period 1 the foreign investors receive a signal about the level of the period-2 return on the investment. For simplicity, we assume that the signal is binomial: the news is good or bad. If the news is good (and foreign investors roll over their loans), $y_{i}=\theta_{i} k_{i}$. If the news is bad but investors nonetheless roll over, then the investment will give a zero return $\left(y_{i}=0\right)$ with probability $\pi>0$.

If period-2 output is higher than the private sector's debt, $y_{i} \geq k_{i}\left(1+r_{i}\right)\left(1+r_{i}^{\prime}\right)$, the loans are fully repaid and the representative entrepreneur consumes output net of the debt repayment. By contrast if $y_{i}<k_{i}\left(1+r_{i}\right)\left(1+r_{i}^{\prime}\right)$ the private sector defaults, foreign creditors collect the output $y$ and the representative resident consumes nothing.

We now make some assumptions that ensure that investors will roll over if and only if the news is good. First, we assume $(1-\pi) \theta_{i}<1$. This says that conditional on bad news the representative entrepreneur is insolvent in period 1 (the expected gross return per unit of capital is less than the debt repayment). We assume that foreign lenders are atomistic and can liquidate the investment with a sequential service constraint. In this case, foreign creditors will not want to roll over their loans in period 1 (conditional on all creditors rolling over, an atomistic foreign creditor is better off asking for repayment, $1+r_{i}$ ). In equilibrium all the creditors run and the investment is fully liquidated. 
By contrast, in the event of good news, foreign lenders are ready to roll over their loans at a zero interest rate $r_{i}^{\prime}$ provided that $\theta_{i}>1+r_{i}$. We assume parameter values such that this condition is satisfied in equilibrium. There is thus a perfect correspondence between bad news about domestic productivity and a crisis (which is both a financial crisis and a capital account crisis since foreign creditors take the proceeds of liquidation out of the country). ${ }^{17}$

In period 0 the government implements a "crisis-prevention effort" which determines the country's vulnerability to a crisis in period 1 . The crisis-prevention effort is denoted by $e_{i, 0}$. It is a continuous variable that takes values in the interval $[\underline{e}, \bar{e}]$.

The probability of bad news as of period 0 is denoted by $p_{i}$. We assume that $p_{i}$ depends on two factors: domestic crisis-prevention effort, and crises abroad. The greater the fraction of economies that develop a crisis in period 1, the higher the probability that the news will be bad and hence that there will be a crisis at home. For analytical tractability, we assume that this negative externality affect the probability of bad news in an additive and linear fashion:

$$
p_{i}=p\left(e_{i, 0}\right)+\lambda n
$$

where the function $p(\cdot)$ is decreasing and convex, $p_{i}=p\left(e_{i, 0}\right)+\lambda \leq 1$, and $0 \leq n \leq 1$. Hence, $\lambda$ captures the strength of "systemic contagion" in this model.

Domestic welfare is given by,

$$
U_{i, t}=E_{i, t}\left(c_{i}\right)-f\left(k_{i}\right)-g\left(e_{i, 0}\right) k_{i}
$$

where $c_{i}$ is the period-2 consumption of the representative resident in country $i, f\left(k_{i}\right)$ is a nonpecuniary cost of operating the capital, and $g\left(e_{i, 0}\right) k_{i}$ is the cost of the effort. The marginal cost of operating capital is increasing with the level of capital (function $f(\cdot)$ is increasing and convex). We assume that the effort cost function $g(\cdot)$ is increasing and convex too.

In sum, the sequence of events and decisions is as follows: at $t=0 \quad e_{i, 0}$ and $k_{i}$ are set simultaneously (respectively, by the domestic government and by the domestic private sector); ${ }^{18}$ at $t=1$ foreign creditors liquidate the investment in the event of bad news, and roll over their loans if news are good; at $t=2$ production and consumption take place.

\footnotetext{
${ }^{17}$ The model also has equilibria with self-fulfilling crises, but we leave this possibility aside in the following.

${ }^{18}$ Thus, there is no moral hazard between the government and the private sector in setting the effort $e_{0}$. As we will see, there would be no moral hazard even if the government or the private sector were a Stackelberg leader.
} 
The level of domestic policy effort is set by the government in period 0 . The government maximizes:

$$
V=\beta\left(z_{i}\right) E_{i, 0}\left(c_{i}\right)-f\left(k_{i}\right)-g\left(e_{i, 0}\right) k_{i}
$$

That is, the government's objective function in period zero is identical to the domestic social welfare function in that period, except for the presence of the discount factor $\beta\left(z_{i, 0}\right) \leq 0$. This discount factor represents a compact way of capturing the effect of domestic policy distortions. $z$ is a positive variable that measures the degree of domestic policy distortion and $\beta(\cdot)$ is a decreasing function. If there is no domestic policy distortion, the government's objective coincides with domestic welfare: $\beta(0)=1$. However, if $z>0$, then the government discounts the future at a higher rate than the representative resident (e.g., because it is run by a policymaker who is not sure to stay in power).

We have set up the model in a way that includes two potential distortions which, as we will show, will generate inefficiently low crisis prevention in equilibrium. When $z>0$, crises will have a larger cost on domestic social welfare than reflected in the government's objective function. And when $\lambda>0$, crises will have a larger cost on global social welfare than is taken into account by each individual government. As we will show, the consequences of these two distortions for the role of the IMF, and in particular for the way in which IMF conditionality should be optimally structured, is very similar. To simplify the exposition, we develop our basic model focusing on just one of these distortions - namely, crisis spillovers on other countriesand then study the effect of the domestic political distortion in an extension. That is, in the remainder of this section, we assume that $\lambda \geq 0$ while $z=0$. This order of discussion is justified by the fact that the main historic motivation for the IMF was the notion that country policies - in particular, trade and exchange rate policies - have spillovers on other countries.

The notion that the IMF attempts to correct domestic policy failures regardless of whether or not country policies have spillovers on other countries is more controversial, though it plays a role both in the literature and (arguably) in practice.

\section{B. Equilibrium Under Laissez-Faire}

In our baseline model, all countries are identical, and we focus on symmetric equilibria. This allows us to ommit country subscripts in what follows in order to simplify the notation.

Ignoring the liquidation value that investors receive in the bad news case (assumed to be very small), the lenders' participation constraint implies $(1-p)(1+r)=1$. Using the fact that expected consumption is equal to expected output net of investment and that $y=0$ in a crisis, the government's objective function can then be written: 


$$
\begin{aligned}
U_{0} & =\left[1-p\left(e_{0}\right)-\lambda E(n)\right] \theta k-k-f(k)-g\left(e_{0}\right) k \\
& =k\left[(\theta-1)-L^{l f}\left(e_{0}\right)\right]-f(k),
\end{aligned}
$$

where $L^{l f}\left(e_{0}\right)$, the net cost of the effort per unit of capital is given by

$$
L^{l f}\left(e_{0}\right) \equiv\left[p\left(e_{0}\right)+\lambda E(n)\right] \theta+g\left(e_{0}\right)
$$

The second term in this expression denotes the direct cost of effort, while the first term, which is declining in $e_{0}$, denotes the expected utility loss of a government associated with a crisis. Maximizing $U$ over $e_{0}$ is equivalent to minimizing $L^{l f}\left(e_{0}\right)$. Note that this problem is independent of both $k$ (which is why the timing of the government's and of the private sector's actions does not matter) and $\lambda E(n)$, since this enters the crisis probability additively, and is taken as given by the government.

Conditional on $e_{0}^{l f}=\arg \min L^{l f}\left(e_{0}\right)$, private lenders lend in period 0 at the interest rate that sets their expected return to zero, given that they are repaid with probability $p\left(e_{0}^{l f}\right)$,

$$
r^{l f}=\frac{1}{1-p\left(e_{0}^{l f}\right)}-1
$$

(where the liquidation value received by investors is again ignored for simplicity). The lenders then roll over their loans at zero interest rate in period 1 if they receive good news, and liquidate the investment if there is bad news.

The domestic private sector sets $k$ so as to maximize:

$$
U_{0}^{l f}=k\left[\theta-1-L^{l f}\left(e_{0}^{l f}\right)\right]-f(k)
$$

Finally, in equilibrium, $E(n)=n=p=p\left(e_{0}^{l f}\right)+\lambda n$, implying $n^{l f}=\frac{p\left(e_{0}^{l f}\right)}{1-\lambda}$.

Proposition 1. In laissez-faire equilibrium, if $\lambda>0$ then crisis prevention effort $e_{0}$ is inefficiently low and the number of crises $n$ is inefficiently high. The larger the spillover parameter $\lambda$, the larger is the discrepancy between the first best and laissez-faire values of $e_{0}$ and $n$. As a result, the interest rate at which the domestic private sector can borrow from abroad is above its first best level, and capital inflows are below their first best level.

Proof. The laissez faire level of effort is obtained by minimizing $L^{l f}\left(e_{0}\right) \equiv\left[p\left(e_{0}\right)+\lambda E(n)\right] \theta+g\left(e_{0}\right)$, 
taking $E(n)$ as given. This leads to the first order condition:

$$
p^{\prime}\left(e_{0}^{l f}\right) \theta+g^{\prime}\left(e_{0}^{l f}\right)=0
$$

In contrast, the first best level of effort is determined taking into account the effect of effort on crises, that is, $e_{0}^{*} \equiv \arg \min L^{*}\left(e_{0}\right)$ where $L^{*}\left(e_{0}\right)$ is defined as:

$$
L^{*}\left(e_{0}\right) \equiv\left\{p\left(e_{0}\right)+\lambda \frac{p\left(e_{0}\right)}{1-\lambda}\right\} \theta+g\left(e_{0}\right)=\frac{p\left(e_{0}\right)}{1-\lambda} \theta+g\left(e_{0}\right)
$$

The first order condition is:

$$
p^{\prime}\left(e_{0}^{*}\right) \theta \frac{1}{1-\lambda}+g^{\prime}\left(e_{0}^{*}\right)=0 .
$$

Comparing the two first order conditions, $e_{0}^{l f}<e_{0}^{*}$ follows from the fact that $\frac{1}{1-\lambda}>1$ and $p^{\prime}(\cdot)<0$ and $g^{\prime}(\cdot)<0$, and the convexity of $p(\cdot)$ and $g(\cdot)$. Since $n=\frac{p\left(e_{0}\right)}{1-\lambda}$ and $r=\frac{1}{1-p\left(e_{0}\right)}-1$, this implies that crises are too frequent, and interest rates too high, relative to the first best. These effects are larger the higher $\lambda$.

Finally, note that because $n^{l f}>n^{*}=\frac{p\left(e_{0}^{*}\right)}{1-\lambda}$, we have $L^{l f}\left(e_{0}\right)>L^{*}\left(e_{0}\right)$ for any given $e_{0}$. Hence, this must also apply to their minima: $L^{l f}\left(e_{0}^{l f}\right)>L^{*}\left(e_{0}^{*}\right)$. The fact that laissez-faire capital inflows are below the first best level light then follows from the first order condition for the domestic private sector, $f^{\prime}(k)=\theta-1-L\left(e_{0}\right)$. Q.E.D.

\section{Equilibrium with IMF Crisis Lending}

We now introduce the following assumption: conditional on bad news the government can make a "crisis-resolution effort" in period 1 , with the effect of raising productivity to $\theta$ with certainty. We assume, for technical convenience, that the crisis-resolution effort is discrete. The dummy variable for the effort will be denoted by $e_{1}$ (equal to 1 if the effort is made, and to 0 otherwise).

Domestic welfare is now given by:

$$
U_{t}=E_{t}\left(c-f(k)-g\left(e_{0}\right) k-e_{1} h\left(e_{0}\right) k\right),
$$

where $h\left(e_{0}\right) k$ is the cost of the crisis-resolution effort in terms of consumption. We assume that good pre-crisis policies not only reduce the probability of a crisis but also reduce the cost of resolving the crisis, if it occurs $(h(\cdot)$ is decreasing). 
Assuming that investors roll over, the output benefit of exercising the crisis resolution effort (compared to the alternative of doing nothing and hoping for the best) is $[\theta-(1-\pi) \theta] k=\pi \theta k$. We assume that the crisis-resolution effort is always efficient in the sense that this output benefit exceeds the cost of the effort regardless of the quality of pre-crisis policies:

$$
h(\underline{e})<\pi \theta \text {. }
$$

However, this does not mean that the government will necessarily want to undertake the effort, because it appropriates only a share of the output benefit: at most, $[(\theta-1)-(1-\pi)(\theta-1)] k=\pi(\theta-1) k$ (the rest goes to the investors - this is the classic debt overhang problem). In the following, we assume that this share is never large enough to make the crisis resolution effort worthwhile for the government:

$$
h(\bar{e})>\pi(\theta-1)
$$

Together, these assumptions determine a time consistency problem. The government would like investors to roll over in order to avoid liquidation. If the government undertakes the crisis resolution effort, rolling over would in fact make sense for investors, since they could expect repayment with certainty. But once investors roll over, the government has an incentive to renege on any such promise. Absent a device for committing the government, private creditors hence do not roll over their claims in equilibrium (just like in the equilibrium of the previous section, in which no crisis resolution technology existed).

This is where the IMF comes in. Unlike private creditors, we assume that the IMF has the ability to elicit the crisis-resolution effort from the government. This assumption is important since it justifies the IMF's existence in terms of a market failure and determines the scope of its intervention. Unlike much of the literature on IMF crisis lending, we assume that the comparative advantage of the IMF is not size per se, but the fact that it can lend in period 1 conditional on the domestic crisis-resolution effort, whereas private creditors cannot. ${ }^{19}$ This advantage of the IMF in imposing conditionality could be due to the IMF's expertise in monitoring country policies (perhaps as a result of spillovers from its surveillance functions) or due to the fact that it is viewed as having greater political legitimacy than private creditors.

\footnotetext{
${ }^{19}$ Of course, the IMF needs to be large enough to undertake the lending. The difference with respect to the literature is that in our model, there is a role for IMF crisis lending regardless of whether private sector lenders are large and/or coordinated or small and dispersed. In other words, the market failure that generates a role for the IMF is not lack of coordination among private lenders, but rather the inability of the private sector to undertake tranched, conditional lending. As a historical matter, there have been rare attempts by banks to play this role, but they have not been successful (see, for example, Rieffel, 2003, on conditional lending by a group of banks to Peru during Peru's 1976-78 balance of payments crisis).
} 
The IMF's ability to lend conditional on the crisis resolution effort — which we interpret as traditional ex post conditionality_implies that it can lend at a zero interest rate $\left(r^{\prime}=0\right)$. The country accepts the IMF's offer provided that the government's net gain from avoiding the liquidation is larger than the cost of the effort: ${ }^{20}$

$$
\theta-(1+r) \geq h\left(e_{0}\right)
$$

Conditionality hence makes it possible for the IMF to intervene without compromising the resources it received from its members (the traditional justification for the development of IMF conditionality). The model also offers an interpretation of why the IMF can lend to crisis countries at a much lower interest rate than the private sector, without losing money over time. Because of IMF conditionality, that lending is essentially risk-free.

If the IMF is expected to rescue the country in the event of a crisis, private creditors lend at a zero interest rate so that the condition above becomes:

$$
\theta-1>h\left(e_{0}\right) .
$$

Note that this condition might be violated for low levels of the crisis-prevention effort. Thus in equilibrium the IMF might not grant crisis lending to countries with bad pre-crisis policies because traditional ex post conditionality does not work in those countries. Indeed, in practice, the IMF often emphasizes that a country's pre-crisis policy "track record" may matter for the decision to lend, because it makes the country's post-crisis policy promises more or less credible. However, this is quite different from a stronger and more explicit form of ex ante conditionality - one that involves a commitment to make countries' access to IMF loans depend on crisis-prevention effort_- to which we will return later in this paper.

The results of this section can be summarized in the following proposition:

Proposition 2. Assume that the IMF can lend to crisis countries conditional on a crisis-resolution effort, whereas private creditors cannot. Then the IMF conditionally lends to all crisis countries that do not have an excessively low level of crisis-prevention effort.

\footnotetext{
${ }^{20}$ Note that the debt overhang problem is still present, in the sense that the government appropriates only $\theta-(1+r)$, rather than the full $\theta$. But if the condition is satisfied, it is nonetheless in the government's interest to accept the IMF's conditional lending offer and exercise the crisis resolution effort, even when it would not have wanted to exercise this effort following a private sector rollover. The reason is that that the alternative to accepting the IMF's offer is receiving nothing, while in the case of the private sector rollover the government could still hope to receive $\theta-(1+r)$ with probability $1-\pi$.
} 


\section{Moral Hazard in the Presence of IMF Crisis Lending}

We now study the effect of (ex post conditional) IMF crisis lending on the government's crisis prevention effort $e_{0}$, and welfare. As emphasized in earlier work (Jeanne and Zettelmeyer, 2005), the two are not necessarily the same. In particular, we show below that the presence of IMF lending may or may not reduce crisis prevention effort; but even when it does, this will imply a welfare reduction only in the presence of sufficiently large "systemic contagion," $\lambda$.

\section{Crisis prevention effort}

For simplicity, we will assume that all countries satisfy the last condition in the previous section, and so accept an IMF program in a crisis. The government's objective function is now,

$$
U_{0}^{i m f}=\left[1-p\left(e_{0}\right)-\lambda E(n)\right] \theta k+\left[p\left(e_{0}\right)+\lambda E(n)\right]\left(\theta k-h\left(e_{0}\right) k\right)-k-f(k)-g\left(e_{0}\right) k .
$$

Compared to the laissez-faire case, there is a new term in the objective function, $\left[p\left(e_{0}\right)+\lambda E(n)\right]\left(\theta k-h\left(e_{0}\right) k\right)$. This reflects the fact that even if there is a crisis, productivity remains high because the representative consumer pays a cost $h\left(e_{0}\right) k$ in period $1 . U_{0}^{i m f}$ can be rewritten as:

$$
U_{0}^{i m f}=k\left[\theta-1-L^{i m f}\left(e_{0}\right)\right]-f(k),
$$

where

$$
L^{i m f}\left(e_{0}\right) \equiv\left[p\left(e_{0}\right)+\lambda E(n)\right] h\left(e_{0}\right)+g\left(e_{0}\right) .
$$

Note the difference between this expression and that for the laissez-faire counterpart $L^{l f}$. The cost of a crisis is no longer the cost of liquidating the investment $\theta$ but the cost of the crisisresolution effort $h\left(e_{0}\right)$, which is lower. The level of crisis prevention effort is given by $e_{0}^{i m f}=\arg \min L^{i m f}\left(e_{0}\right)$, taking $E[n]$ as given. The first-order condition of the government's problem is:

$$
\left[p\left(e_{0}^{i m f}\right)+\lambda E(n)\right] h^{\prime}\left(e_{0}^{i m f}\right)+p^{\prime}\left(e_{0}^{i m f}\right) h\left(e_{0}^{i m f}\right)+g^{\prime}\left(e_{0}^{i m f}\right)=0 .
$$

Using the fact that $E[n]=n^{i m f}=\frac{p\left(e_{0}^{i m f}\right)}{1-\lambda}$, this gives

$$
p\left(e_{0}^{i m f}\right) \frac{1}{1-\lambda} h^{\prime}\left(e_{0}^{i m f}\right)+p^{\prime}\left(e_{0}^{i m f}\right) h\left(e_{0}^{i m f}\right)+g^{\prime}\left(e_{0}^{i m f}\right)=0 \text {. }
$$

To see the impact of the IMF on the effort level, we need to compare this condition to the analogous first-order condition under laissez-faire:

$$
p^{\prime}\left(e_{0}^{l f}\right) \theta+g^{\prime}\left(e_{0}^{l f}\right)=0 .
$$


First, assume that the cost of the crisis-resolution effort does not depend on the quality of precrisis policies $\left(h^{\prime}=0\right)$. Then the first-order condition is the same as under laissez-faire with $\theta$ replaced by $h\left(e_{0}^{i m f}\right)<\theta$. Thus the marginal benefit of $e_{0}$ is lower with the IMF, implying $e_{0}^{i m f}<e_{0}^{l f}$. This is sometimes referred to as the "country moral hazard" effect of IMF lending: because the IMF reduces the cost of the crisis, the country undertakes a smaller crisisprevention effort.

Second, assume that the quality of pre-crisis policies matters for the size of the post-crisis effort $\left(h^{\prime}<0\right)$. Then the existence of IMF programs increases the marginal benefit of $e_{0}$, leading to an improvement in the quality of domestic policies. This is an "effort substitution" effect: countries implement better policies ex ante to reduce the cost of conditionality ex post in a crisis. This effect is captured by the first term in the first-order condition. As a result, it may be the case that $e_{0}^{i m f}>e_{0}^{l f}$.

Proposition 3. The impact of the IMF on the crisis-prevention effort is ambiguous in equilibrium. On the one hand, IMF lending reduces the cost of a crisis and so reduces the incentives to good policies. On the other hand, the country internalizes the fact that the ex post crisis resolution effort depends on the level of crisis-prevention effort. If the second effect dominates, IMF lending could induce more crisis prevention.

Note that the size of the effort substitution effect is growing in the size of the systemic contagion effect $\lambda$ : the higher $\lambda$, the higher the probability of crises for any given $e_{0}$, and hence the higher the incentive to invest in effort $e_{0}$ to reduce the cost of conditionality ex post.

\section{Example}

Assume $\lambda=0$ and

$$
\begin{gathered}
p(e)=1-e, \\
g(e)=e^{2} / 2 \alpha \\
h(e)=\theta(1-e)
\end{gathered}
$$

Then,

which yields

$$
\begin{gathered}
L_{0}^{l f}(e)=p(e) \theta+g(e)=(1-e) \theta+\frac{e^{2}}{2 \alpha} \\
L_{0}^{i m f}(e)=p(e) h(e)+g(e)=\theta(1-e)^{2}+\frac{e^{2}}{2 \alpha}
\end{gathered}
$$

$$
e_{0}^{l f}=\alpha \theta
$$


and

$$
e_{0}^{i m f}=\frac{2}{1+2 \alpha \theta} \alpha \theta=\frac{2}{1+2 e_{0}^{l f}} e_{0}^{l f}
$$

Hence, $e_{0}^{i m f}>e_{0}^{l f}$ if and only if $e_{0}^{l f}=\alpha \theta<1 / 2$.

\section{Welfare}

To compare welfare in the IMF and laissez-faire regime, note first that equilibrium welfare can be written as:

$$
\max _{k} U_{0}^{*}\left(e_{0}^{l f}, k\right) \equiv \max _{k}\left\{k\left[\theta-1-L^{*}\left(e_{0}^{l f}\right)\right]-f(k)\right\}
$$

in the regime without the IMF, and similarly as

$$
\max _{k} U_{0}^{i m f^{*}}\left(e_{0}^{i m f}, k\right) \equiv \max _{k}\left\{k\left[\theta-1-L^{i m f^{*}}\left(e_{0}^{i m f}\right)\right]-f(k)\right\}
$$

in the regime with the IMF, where $L^{i m f^{*}}\left(e_{0}\right)$ is defined analogously to $L^{*}\left(e_{0}\right)$, that is, as the loss function after taking into account the external effects of prevention effort on crises:

$$
L^{i m f^{*}}\left(e_{0}\right) \equiv \frac{p\left(e_{0}\right)}{1-\lambda} h\left(e_{0}\right)+g\left(e_{0}\right)
$$

Clearly, for any given $k, U_{0}^{i m f^{*}}\left(e_{0}^{i m f}, k\right)>U_{0}^{*}\left(e_{0}^{l f}, k\right)$ if and only if $L^{i m f^{*}}\left(e_{0}^{i m f}\right)<L^{*}\left(e_{0}^{l f}\right)$. Hence, this must also be true for $\max _{k} U_{0}^{i m f^{*}}\left(e_{0}^{i m f}, k\right)$ and $\max _{k} U_{0}^{*}\left(e_{0}^{l f}, k\right)$. To compare the two regimes in terms of welfare, it is thus enough to compare $L^{i m f *}\left(e_{0}^{i m f}\right)$ and $L^{*}\left(e_{0}^{l f}\right)$.

Consider first the case where $\lambda=0$, i.e., there is no systemic contagion. In this case, we have:

$$
L^{*}\left(e_{0}\right)=L^{l f}\left(e_{0}\right)=p\left(e_{0}\right) \theta+g\left(e_{0}\right)
$$

and

$$
L^{i m f *}\left(e_{0}\right)=L^{i m f}\left(e_{0}\right)=p\left(e_{0}\right) h\left(e_{0}\right)+g\left(e_{0}\right)
$$

Since $\theta-1>h\left(e_{0}\right), L^{i m f}\left(e_{0}\right)<L^{l f}\left(e_{0}\right)$ for any choice of $e_{0}$. Hence, $L^{i m f}\left(e_{0}^{i m f}\right)<L^{l f}\left(e_{0}^{l f}\right)$, even though it is possible (as shown in the previous section) that $e_{0}^{i m f}<e_{0}^{l f}$. In other words, if $\lambda=0$, the presence of IMF crisis lending always improves welfare, even though it may well lead to 
lower crisis prevention effort. ${ }^{21}$ Hence, calling lower crisis prevention effort "moral hazard" in this context is really a misnomer, since the presence of the IMF does not create (or magnify) any distortion. The lower crisis prevention effort is merely an efficient response to a less risky environment. So are lower interest rates (compared to laissez faire, the private sector lends at a zero rate, since crises no longer occur) and higher capital flows ( $k$ is higher compared to the laissez faire state, since borrowing is cheaper), that are often viewed as indicative of "creditor moral hazard."

However, the availability of IMF crisis lending could in fact decrease welfare in the presence of systemic contagion. Consider an example with $p(e)=1-e, g(e)=\alpha e$, and $h\left(e_{0}\right)=\gamma<\theta-1$. Because of the linearity of these functions, the equilibrium crisis prevention effort $e$ is then equal to either $\bar{e}=1$ or $\underline{e}=0$. More precisely,

$$
\begin{gathered}
e_{0}^{l f}=\arg \min \left\{\left(1-e_{0}\right) \theta+\alpha e_{0}\right\}=1 \text { iff } \alpha<\theta, \\
e_{0}^{i m f}=\arg \min \left\{\left(1-e_{0}\right) \gamma+\alpha e_{0}\right\}=0 \text { iff } \alpha>\gamma .
\end{gathered}
$$

Assume that $\gamma<\alpha<\theta$, so that the IMF decreases crisis prevention effort from 1 to 0 . Using the assumed functional forms, $L^{i m f^{*}}\left(e_{0}^{i m f}\right)$ and $L^{*}\left(e_{0}^{l f}\right)$ can be written:

$$
L^{i m f *}\left(e_{0}^{i m f}\right)=\frac{p\left(e_{0}^{i m f}\right)}{1-\lambda} \gamma+g\left(e_{0}^{i m f}\right)=\frac{1-e_{0}^{i m f}}{1-\lambda} \gamma+\alpha e_{0}^{i m f}
$$

and

$$
L^{*}\left(e_{0}^{l f}\right)=\frac{p\left(e_{0}^{l f}\right)}{1-\lambda} \theta+g\left(e_{0}^{l f}\right)=\frac{1-e_{0}^{l f}}{1-\lambda} \theta+\alpha e_{0}^{l f} .
$$

Hence, $L^{i m f *}\left(e_{0}^{i m f}\right)>L^{*}\left(e_{0}^{l f}\right)$ if and only if:

$$
\frac{1-0}{1-\lambda} \gamma+\alpha \cdot 0>\frac{1-1}{1-\lambda} \theta+\alpha \cdot 1
$$

that is, if $\lambda>1-\frac{\gamma}{\alpha}$. Hence, we have found an example in which the IMF decreases welfare in the presence of contagion effects above a given threshold. Note also that in the case of $\lambda=0$, the inequality above reduces to $\gamma>\alpha$, in contradiction with the assumed parameter values. This confirms, in the context of this example, that under $\lambda=0, L^{i m f^{*}}\left(e_{0}^{i m f}\right) \leq L^{*}\left(e_{0}^{l f}\right)$.

\footnotetext{
${ }^{21}$ This result has been referred to as the "Mussa Theorem," after the IMF's former chief economist, Michael Mussa (see Mussa, 1999, 2004; and Jeanne and Zettelmeyer, 2005, for a formal statement). In Mussa's original formulation, emphasis is put on the fact the IMF cannot be a source of moral hazard provided it is always repaid. The latter is assumed in the setup of our model.
} 
We summarize this discussion as follows:

Proposition 4. With traditional (ex post) conditionality, IMF crisis lending improves welfare if there is no systemic contagion, but may decrease welfare in the presence of sufficiently high levels of systemic contagion.

\section{E. The Case for ex ante Conditionality}

Proposition 4 show that in the presence of an addition distortion-here, we emphasize systemic contagion; below, we will show that a similar problem arises with domestic political economy distortions - standard conditional IMF lending could do more harm than good, by discouraging crisis prevention effort. However, there is a straightforward way of dealing with this problem, namely, to apply conditionality to crisis-prevention effort directly. In this section, we show how this "ex ante conditionality" would work, and explore its welfare implications.

The (optimal) level of crisis prevention effort required by the IMF under "ex ante conditionality" is set as follows. Let $\tilde{e}_{0}$ denote the highest level crisis prevention effort that a country is willing to undertake ex ante in exchange for access to IMF lending ex post. This is the highest level of effort satisfying the incentive condition,

$$
L^{i m f}\left(e_{0}\right) \leq L^{l f}\left(e_{0}^{l f}\right) .
$$

Furthermore, let $e_{0}^{i m f *}$ denote the first best level of the level of effort in the presence of IMF lending, taking into account the effect of effort on the total number of crises:

$e_{0}^{i m f^{*}} \equiv \arg \min L^{i m f^{*}}\left(e_{0}\right)$, where $L^{i m f^{*}}\left(e_{0}\right)$ was defined in equation (4). Then, "ex ante conditionality" is a lending policy which requires countries to exercise the effort level $e_{0}^{e a}$ in exchange for access to IMF crisis lending, where

$$
e_{0}^{e a} \equiv \min \left(\tilde{e}_{0}, e_{0}^{i m f^{*}}\right) \text {. }
$$

In other words, ex ante conditionality requires countries to either undertake the first best crisis prevention effort or - if this is not feasible, in the sense that countries prefer to forego the option to borrow from the IMF rather than exercise the first-best policy effort - the highest effort level that countries are willing to undertake in exchange for access to IMF financing in a crisis.

Proposition 5. If there is a positive level of systemic contagion $(\lambda>0)$, ex ante conditionality is welfare-enhancing relative to both laissez-faire and relative to IMF lending without ex ante conditionality. Ex ante conditionality reduces the probability of a crisis and the cost of ex post conditionality.

Proof. The first statement follows from the fact that $e_{0}^{i m f}$ and $e_{0}^{l f}$ both satisfy the incentive condition (5). Hence, the IMF can achieve, with ex ante conditionality, a welfare level that is at least as good as without ex ante conditionality or under laissez-faire. The last statement follows 
directly from $e_{0}^{e a}>e_{0}^{i m f}$, which is true because $e_{0}^{i m f *}>e_{0}^{i m f}$ and $\tilde{e}_{0}>e_{0}^{i m f}$ (since $e_{0}^{i m f}$ satisfies the incentive constraint (5)). Q.E.D.

Ex ante conditionality gives the IMF an additional tool to influence crisis prevention policies. If there is systemic contagion, it is always optimal to use this tool. Furthermore the IMF with optimal ex ante conditionality can never be worse than laissez-faire because the laissez-faire level of crisis prevention effort belongs to the set of efforts that can be induced by ex ante conditionality.

\section{DiscuSSION AND EXTENSIONS}

\section{A. Incomplete Information and Imperfect Commitment by the IMF}

In introducing the concept of ex ante conditionality, we have implicitly assumed (1) that the IMF can commit to the ex ante conditions, so that they are fully credible, and (2) that crisis prevention effort is perfectly observable. What if these assumptions are violated?

If ex ante conditionality is not fully credible, then countries are likely to undertake less prevention than required by the IMF, on the grounds that a welfare-maximizing IMF will be tempted to rescue them anyway in the event of a crisis - especially if the ex post safety net provided by the IMF is generous. If this is the case, crisis prevention will be suboptimally low, but it will never be less than in a regime in which there is only ex post conditionality. The conclusion that the regime with ex ante conditionality dominates the regime without hence seems robust along this dimension (credibility).

Incomplete information about the prevention effort (or, equivalently, about the effectiveness of policy effort of a certain kind with respect to crisis prevention) creates a trickier problem. In this case, ex ante conditionality would need to be written with respect to a noisy signal of the true crisis prevention effort, either because the effort variable(s) cannot be observed precisely, or because of uncertainty over which policy variables are truly relevant. This could lead both to "Type I errors" (lend to countries that undertook too little effort) and "Type II errors" (deny lending to countries even though they undertook the required effort).

As far as the Type I errors are concerned, ex ante conditionality can never do worse than the regime with ex post conditionality only. However, it might do worse on the grounds that it makes too many Type II errors, i.e., excludes too many "deserving" countries from lending. For any given level of observed effort $e_{0}^{e a}$ required by ex ante conditionality, there should be a degree of noisiness in the signal such that ex ante conditionality lowers welfare relative to the regime without any ex ante conditionality. At the same time, one would conjecture that this can be addressed by making the ex ante policy sufficiently "permissive" depending on the noisiness of the signal, i.e. by decreasing $e_{0}^{e a}$ relative to its level under complete information. Only in the 
limit (that is, for completely uninformative signals) will $\tilde{e}_{0}=0$, i.e. will the optimal ex ante policy coincide with the regime without any ex ante conditionality.

Based on these arguments, some form of ex ante conditionality is likely to be welfare improving even in situations with limited credibility and noisy signals. This said, in the presence of noisy signals (or uncertainty about the "right model" for crisis prevention) the optimal ex ante conditionality would need to be modified relative to the policy defined in the previous section, in the direction of imposing less stringent conditions ex ante.

\section{B. Large versus Small Countries}

In the baseline model, we have assumed that all countries are "large" in the sense that they impose a crisis externality on others. What happens if this is not the case, in the sense that some countries are so "small" that they do not impose this externality? The answer is that all results of the baseline model go through, except that ex ante conditionality now makes sense only for the "large" countries, since only in these countries crisis prevention effort involves a social cost that is not fully internalized by the government (we maintain the assumption that there are no domestic political distortions for the time being). In contrast, ex post conditionality continues to make sense for all countries, since the rationale for this — providing commitment — had nothing to do with crisis externalities (it would apply even in a one country model). ${ }^{22}$

\section{Distortions Related to Domestic Political Economy}

We now turn to a possible alternative reason why governments may underinvest in crisis prevention effort, and hence an alternative rationale for ex ante conditionality, namely, a domestic political economy distortion. We foreshadowed this possibility in the setup of our model by allowing the government's discount factor to be smaller than the social discount factor (perhaps reflecting short political horizons). That is, while the social welfare function of country $i$ is

$$
U_{i, t}=E_{i, t}\left(c_{i}\right)-f\left(k_{i}\right)-g\left(e_{i, 0}\right) k_{i}
$$

while the government maximizes:

$$
V_{i}=\beta\left(z_{i}\right) E_{i, 0}\left(c_{i}\right)-f\left(k_{i}\right)-g\left(e_{i, 0}\right) k_{i}
$$

where $z$ is a positive variable that measures the degree of domestic policy distortion and $\beta(\cdot)$ is a decreasing function, with $\beta(0)=1$.

\footnotetext{
${ }^{22}$ The details of this extension of the model are available upon request to the authors.
} 
In the baseline model, we assumed $z=0$ in order to concentrate on the distortion associated with systemic contagion, $\lambda \geq 0$. We now make the reverse assumption, that is $z \geq 0$ and $\lambda=0$. Consequently, $p_{i}=p\left(e_{0, i}\right)$, i.e. the probability of a crisis depends only on the government's own actions and not on that of other governments. For this reason, the cross-country dimension no longer plays a role, and we drop the country subscript $i$ in what follows.

We redefine the four loss functions defined earlier in equations (1) - (4) as follows:

$$
\begin{gathered}
L^{l f}\left(e_{0}\right)=\beta(z) p\left(e_{0}\right) \theta+g\left(e_{0}\right) \\
L^{i m f}\left(e_{0}\right)=\beta(z) p\left(e_{0}\right) h\left(e_{0}\right)+g\left(e_{0}\right) \\
L^{*}\left(e_{0}\right)=p\left(e_{0}\right) \theta+g\left(e_{0}\right) \\
L^{i m f^{*}}\left(e_{0}\right)=p\left(e_{0}\right) h\left(e_{0}\right)+g\left(e_{0}\right)
\end{gathered}
$$

As before, $L^{l f}\left(e_{0}\right)$ and $L^{i m f}\left(e_{0}\right)$ describe the loss associated with crises and crisis prevention effort from the perspective of the government, while $L^{*}\left(e_{0}\right)$ and $L^{i m f^{*}}\left(e_{0}\right)$ describe it from a social perspective. The difference is that, before, the distinction between the government and social perspectives consisted in that the former took crises abroad as given, while the latter reflected the number of crises in equilibrium. Now, the distinction consists in the different discount rates of the government and the social planner.

With these redefinitions, the analysis of this version of the model turns out to be almost exactly analogous to the baseline model. Here, we do not go through each step, but merely highlight the main results, and the (few) differences. ${ }^{23}$

- Under laissez faire, the government underinvests in crisis prevention, resulting in crisis risk and country borrowing rates that are too high relative to the first best, and capital flows that are too low, just as in the baseline model (Proposition 1). This is because the government discounts the costs of potential crises, which are in the future, too much relative to the costs of preventing them, which are in the present.

- $\quad$ The rationale for standard IMF lending remains unchanged, that is, to provide commitment in the face of a time consistency problem that arises in the context of crisis mitigation, with IMF lending critical to secure that commitment.

\footnotetext{
${ }^{23}$ For a full development of the model, see a previous version of this paper (Jeanne, Ostry and Zettelmeyer, 2007, available on request).
} 
- $\quad$ The effects of standard IMF lending on crisis mitigation effort are also unchanged. There continues to be both a "moral hazard" effect (from the fact that crises are less costly than without the IMF) and an effort substitution effect (higher crisis prevention effort means lower crisis mitigation effort). Depending on which effect dominates, crisis prevention effort can go up or down. The only difference is in the way in which the distortion interacts with the effort substitution effect. With a domestic political economy distortion, the relative size of the effort substitution effect is decreasing in the distortion, since the cost of crisis mitigation is discounted more. In contrast, in the model with systemic contagion, a higher contagion parameter tended to increase the probability of a crisis for a given level of effort, and hence the incentive to invest in effort to reduce the cost of crisis mitigation.

- $\quad$ As before, IMF conditionality can be welfare reducing if crisis prevention effort goes down. Whether this is the case or not depends on the size of the political economy distortions. Intuitively, if there is no political economy distortion, then any reduction in prevention effort would just be an efficient response to the safer environment that comes from the presence of the IMF. This would improve welfare. Only in the presence of the distortion will the reduction in effort go beyond what is socially justified. If prevention effort goes down excessively, the detrimental effect on crisis prevention will more than offset the welfare gains that come from better crisis mitigation due to the presence of the IMF.

- When effort is inefficiently low in the presence of IMF crisis mitigation, then ex ante conditionality can be used to raise it and improve welfare, for the same reasons as in the baseline model: namely, because the country is willing to exert extra effort to maintain the option of accessing IMF crisis lending in the event of a crisis.

Finally, note one subtle difference between political economy distortions and cross-country externalities: the former (but not the latter) could potentially be addressed not just through ex ante conditionality on effort, but also by excluding some countries from IMF lending based on country characteristics such as the quality of governance. However, it turns out that this brand of "selectivity" is dominated, in a welfare sense, by ex ante conditionality as described in this paper, since the latter might induce some poor governance countries to exercise the required prevention effort and hence benefit from access to IMF lending. In contrast, under ex ante conditions focused on the political distortions themselves, those countries would simply be excluded from IMF lending.

\section{Conclusion}

This paper has attempted to clarify the financial role of the IMF that evolved since the 1950s, characterize the conditions under which this role may distort incentives and give rise to moral hazard, and suggest a reform - namely a greater role of ex ante conditionality in IMF lending operations - which would eliminate this distortion. The main insights are as follows. 
First, traditional (ex post) conditionality can be rationalized as the solution to a commitment problem. In a situation in which a country experiences a sudden stop which involves some deterioration in the country's solvency, crisis resolution will require some policy effort, or "adjustment" in the IMF's terminology. It will also require liquidity, e.g. a rollover by existing creditors, or new investment. Creditors would in fact roll over, and confidence would return, provided that the government undertakes the policy effort. But once that happens, the government will have an incentive to renege on its adjustment promise. Anticipating that, there is no rollover. IMF conditionality is a device that solves this problem, by committing the government to carry out the effort. The justification for the IMF (in this context) is its institutional capacity to make that commitment stick, through a process of tranched crisis lending and conditionality discussed in Section II. By doing so, the Fund helps to avoid or shorten crises and - subject to a caveat, see below-improves welfare.

Second, IMF lending with ex post conditionality can be a source of moral hazard, but only under specific conditions:

- $\quad$ Consider first its effect on crisis prevention effort on the side of the government. In general, this is ambiguous. On the one hand, IMF lending reduces the cost of a crisis and so reduces prevention incentives. However, countries also understand that the cost of carrying out adjustment in the context of an IMF supported program will be lower the higher the crisis-prevention effort. If this "effort substitution effect" dominates, IMF lending could induce more crisis prevention.

- $\quad$ Next, suppose that the presence of IMF lending does indeed reduce crisis prevention effort. Does this mean that the IMF is a source of moral hazard? Not necessarily, because the reduction in effort could be an efficient response- one that occurs at noone's expense - to a safer international environment. This will be the case, specifically, if IMF lending does not carry a subsidy, if debtor governments maximize domestic welfare, and if there are not crisis or policy externalities across countries. If these conditions are satisfied (or if any violation is small), then IMF crisis lending will be welfare improving, even if it leads to lower crisis prevention effort.

- If, however, there are large crisis externalities across countries, or significant discrepancies between the interests of governments and societies as a whole, then IMF crisis lending could be welfare reducing. In those cases, the government will underinvest in crisis prevention relative to the social optimum, either because it does not internalize the international benefits of crisis prevention, or because it discounts the costs of crisis resolution too much (compared to the social burden).

Third, the paper shows how moral hazard associated with IMF crisis lending can be avoided, namely, by applying conditionality to the country's crisis prevention effort, i.e. to the quality of economic policies and institutions. Optimal ex ante conditionality involves either asking the country to implement the first best policy effort in the presence of IMF lending (which may be 
lower than the first best effort without the IMF, given the reduced risk) or, if this is not feasible, the highest policy effort that the country is prepared to exercise in exchange for access to IMF lending in a crisis.

While the basic case for ex ante conditionality is straightforward, applying it successfully raises some difficult problems (see Ostry and Zettelmeyer, 2005, for a more detailed discussion). The first is what ex ante conditions should look like. Adequate crisis prevention in one area will depend on the strength of policies in other areas, on the characteristics of the economy, and on the economic cycle. Hence, it seems unlikely that prequalification could be purely rules based; it would require some element of discretion. One way of exercising this discretion might be in the context of the IMF's regular surveillance process.

The second problem is related to time consistency. Once a member country has run into trouble, the optimal action going forward will be to allow it to borrow whether or not it has undertaken adequate prevention efforts ex ante. Denying countries which fail to meet ex ante conditions a loan (or at least a high-access loan) would require a high capacity to commit on the side of the IMF. The commitment capacity may be even higher than that needed to make conventional IMF programs work, in which a similar time consistency problem arises when denying new loan tranches to important borrowers who have failed to meet a performance criterion. A governance structure embodying enhanced operational independence and strengthened medium-run accountability would provide an important vehicle to address this time-consistency problem. 


\section{References}

Barro, Robert, 1998, “The IMF Doesn’t Put Out Fires, It Starts Them,” Business Week, December 7.

Boughton, J.M, 2001, The Silent Revolution. The International Monetary Fund, 1979-1989 (Washington, D.C.: International Monetary Fund).

Calomiris, Charles W. 1998a, “The IMF's Imprudent Role as Lender of Last Resort," Cato Journal, Vol. 17, No. 3, pp. 275-94.

_ $1998 \mathrm{~b}$, "Blueprints for a New Global Financial Architecture” (unpublished; Washington: available on the website of the American Enterprise Institute, http://www.aei.org).

Chami, Ralph, Sharma, Sunil and Ilhyock Shim, 2004, "A Model of the IMF as a Coinsurance Arrangement," IMF Working Paper 04/219.

Clark, Peter, and Haizhou Huang, 2001, "International Financial Coordination and the IMF: A Theoretical Framework," IMF Working Paper WP/01/137.

Cohen, Daniel, and Richard Portes, 2004, “Towards a Lender of First Resort," CEPR Discussion Paper No. 4615 (London: Center for Economic Policy Research).

Cordella, Tito, and Eduardo Levy Yeyati, “A (New) Country Insurance Facility,” IMF Working Paper 05/23 (Washington: International Monetary Fund).

Corsetti, Giancarlo, Guimaraes, Bernardo and Nouriel Roubini, 2006, "International Lending of Last Resort and Moral Hazard: A Model of IMF's Catalytic Finance," Journal of Monetary Economics 53, 441-471.

Council on Foreign Relations Task Force (1999). "Safeguarding Prosperity in a Global Financial System: The Future International Financial Architecture", Washington D.C.: Institute for International Economics.

de Gregorio, José, Barry Eichengreen, Takatoshi Ito and Charles Wyplosz, An Independent and Accountable IMF, Geneva Reports on the World Economy Report 1, Centre for Economic Policy Research, September 2000.

de Resende, Carlos, "IMF Supported Adjustment Programs: Welfaqre Implications and the Catalytic Effect," Working Paper 2007-22 (Ottawa: Bank of Canada).

Drazen, Allen, "Conditionality and Ownership in IMF Lending: A Political Economy Approach,” IMF Staff Papers, Vol. 49, Special Issue, pp. 36-67. 
Eichengreen, Barry (2000), Can the Moral Hazard Caused by IMF Bailouts be Reduced? Geneva Reports on the World Economy Special Report 1, Centre for Economic Policy Research, September 2000.

Erbas, S. Nuri, 2003, "IMF Conditionality and Program Ownership: A Case for Streamlined Conditionality," IMF Working Paper 03/98.

Federico, Giulio, 2001, “IMF Conditionality,” Economics Papers 2001-W19, Economics Group, Nuffield College, University of Oxford.

Fleming, J. Marcus, 1964, The International Monetary Fund: Its Form and Functions (Washington: International Monetary Fund).

Frech, Tim, Internationale Verschuldungskrisen, die Kreditvergabepolitik des IWF und Schuldner-Moral-Hazard: Eine Analyse aus vertragstheoretischer Sicht (Bern: Studienzentrum Gerzensee).

Gale, Douglas, and Xavier Vives, 2002 "Dollarization, Bailouts, and the Stability of the Banking System," Quarterly Journal of Economics (May), pp. 467-502.

Haldane, Andrew G., and Mark Kruger, 2001, "The Resolution of International Financial Crises: Private Finance and Public Funds," Bank of England Financial Stability Review, November.

Haque, Nadeem U1 and Mohsin S. Khan, 1998, "Do IMF-Supported Programs Work?” A Survey of the Cross-Country Empirical Evidence, Working Paper No. 98/169, December (Washington: International Monetary Fund).

Horsefield, J. Keith, The International Monetary Fund 1945-1965: Twenty Years of International Monetary Cooperation, Volume I: Chronicle (Washington: International Monetary Fund).

International Financial Institution Advisory Commission, 2000, "Report of the International Financial Institution Advisory Commission', Allan H. Meltzer, Chairman, Washington DC, March (also referred to above as the "Meltzer Report").

International Monetary Fund (IMF), 2006, Consideration of a New Liquidity Instrument for Market Access Countries, available online at http://www.imf.org/external/np/pp/eng/2006/080306.pdf

— 2007a, Further Consideration of a New Liquidity Instrument for Market Access Countries - Design Issues, available online at http://www.imf.org/external/np/pp/eng/2007/021307.pdf

— $2007 \mathrm{~b}$, Factsheet—The Multilateral Debt Relief Initiative (MDRI), available online at http://www.imf.org/external/np/exr/facts/mdri.htm 
Ivanova, Anna, 2006, “Outcomes-Based Conditionality: Its Role and Optimal Design,” IMF Working Paper 06/128.

Jeanne, Olivier, and Charles Wyplosz, 2001, “The International Lender of Last Resort: How Large is Large Enough?” NBER Working Paper No.8381 (Cambridge, Massachusetts: National Bureau of Economic Research).

Jeanne, Olivier, and Jeromin Zettelmeyer, 2001a, "International Bailouts, Moral Hazard and Conditionality,” CESifo Working Paper No. 563, September.

__ 2001b, "International Bailouts, Moral Hazard and Conditionality," Economic Policy $33,409-32$.

_ 2002, “ 'Original Sin,' Balance Sheet Crises, and the Roles of International Lending,” IMF Working Paper WP/02/234.

— 2005, "The Mussa Theorem (and Other Results on IMF-Induced Moral Hazard)," IMF Staff Papers, Vol. 52, Special Issue, pp. 64-84.

Jeanne, Olivier, Jonathan Ostry, and Jeromin Zettelmeyer, 2007, "Crisis Lending, Moral Hazard, and Conditionality," (paper presented at CREI/CEPR conference on "Financial Crises: Past, Theory and Future," Barcelona, June 2007).

Joyce, Joseph P., "Promises Made, Promises Broken: A Model of IMF Program Implementation" . Economics \& Politics, Vol. 18, No. 3, pp. 339-365, November 2006

Khan, Mohsin S. and Sunil Sharma, 2001, "IMF Conditionality and Country Ownership of Programs," IMF Working Paper 01/142.

Kenen, Peter, 2001, The International Financial Architecture: What's New? What's Missing? (Washington: Institute for International Economics).

Kim, Jun Il, 2006, “IMF-supported Programs and Crisis Prevention: An Analytical Framework," IMF Working Paper 06/156. , 2007, "Unconditional IMF Lending and Investor Moral Hazard,” mimeo.

Marchesi, Sylvia, and Jonathan P. Thomas, 1999, "IMF Conditionality as a Screening Device," Economic Journal, Vol. 109 (March), pp. C111-C125.

Mayer, Wolfgang and Alex Mourmouras, 2002, "Vested Interests in a Positive Theory of IFI Conditionality," IMF Working Paper 02/73. , 2004, "The Political Economy of Conditional and Unconditional Foreign Assistance: Grants vs. Loan Rollovers," IMF Working Paper No. 04/38. 
, 2005, "On the Viability of Conditional Assistance Programs," IMF Working Paper No. $05 / 121$.

Miller, Marcus, and Lei Zhang, 2000, "Sovereign Liquidity Crises: The Strategic Case for a Payments Standstill," Economic Journal, Vol. 110 (January). pp. 335-62.

Mody, Ashoka, and Diego Saravia, 2003, Catalyzing Capital Flows: Do IMF-Supported Programs Work as Commitment Devices? IMF Working Paper No. 03/100.

Morris, Steve, and Hyun Song Shin, 2006, “Catalytic Finance: When Does It Work?” Journal of International Economics 70, 161-177.

Mourmouras, Alex, and Peter Rangazas, 2004, “Conditional Lending Under Altruism,” IMF Working Paper 04/100.

Mussa, Michael, 1999, "Reforming the International Financial Architecture: Limiting Moral Hazard and Containing Real Hazard," in Capital Flows and the International Financial System, ed. by David Gruen and Luke Gower (Sidney: Reserve Bank of Australia), 21636.

— 2004, "Reflections on Moral Hazard and Private Sector Involvement in the Resolution of Emerging Market Financial Crises," in Fixing Financial Crises in the Twenty-first Century, 2004, ed. by Andy Haldane (London: Routledge), pp. 33-51.

Ostry, Jonathan and Jeromin Zettelmeyer, 2005, "Strengthening IMF Crisis Prevention," IMF Working Paper 05/206.

Penalver, Adrian, 2004, "How can the IMF Catalyse Private Capital Flows? A Model," Bank of England Working Paper No. 215.

Polak, Jacques J., 1991, “The Changing Nature of IMF Conditionality,” Essays in Interantional Finance No. 184 (Princeton: Princeton University Press).

Rieffel, Lex, 2003, Restructuring Sovereign Debt. The Case for Ad Hoc Machinery (Washington: Brookings Institution).

Rochet, Jean-Charles, and Xavier Vives, 2004, "Coordination Failures and the Lender of Last Resort: Was Bagehot Right After All?," Journal of the European Economic Association 2 (6), pp. 1116-1147.

Sachs, Jeffrey, 1984, “Theoretical Issues in International Borrowing," Princeton Studies in International Finance 54 (Princeton: Princeton University Press).

_ 1995, "Do We Need an International Lender of Last Resort?" Frank D. Graham Lecture at Princeton University, Vol. 8, April 20. 
Spitzer, Emil G., 1969, "Stand-By Arrangements: Purposes and Form, in J. Keith Horsefield, The International Monetary Fund 1945-1965: Twenty Years of International Monetary Cooperation, Volume II: Analysis (Washington: International Monetary Fund), pp. 468491.

Tirole, Jean, 2002, Financial Crises, Liquidity, and the International Monetary System (Princeton: Princeton University Press).

Vaubel, Roland, 1983, “The Moral Hazard of IMF Lending,” The World Economy, pp. 291-304;

— , 1988, “The Political Economy of International Organisations in International Money and Finance," Tenth Henry Thornton Lecture (London: City University).

Weithöner, Thomas, 2006, "How can IMF policy eliminate country moral hazard and account for externalities?" Journal of International Money and Finance, Vol. 25, No. 8, Pages 1257-1276.

Vreeland, James R., 1999, “The IMF: Lender of Last Resort or Scapegoat?” presented at the International Studies Association Conference, Washington DC.

— 2003, The IMF and Economic Development (Cambridge: Cambridge University Press).

Zettelmeyer, Jeromin, 2000, "Can Official Crisis Lending be Counterproductive in the Short Run?”, Economic Notes Vol. 29, No. 1, pp. 13-29.

Zettelmeyer, Jeromin and Priyadarshani Joshi, 2005, "Implicit Transfers in IMF Lending," International Monetary Fund Working Paper WP/05/8. 